economics, is to be arranged. It has not yet been possible to proceed with the study of transport and communications.

\title{
The need for training of Officials in South Africa
}

IN the course of a Presidential Address to section $E$ of the South Aftican Association for the Advancement of Science in July 1939, Professor I. Schapera made this remark: "It is somewhat ironic that in a country where at least six Universities and University Colleges have Departments of Bantu Studies, none of these Departments is actively engaged in preparing candidates for acceptance by the Native Affairs Department, although several young South Africans who have made a special study of Native life and languages have found their qualifications a decided asset for admission into the Rhodesian and British Colonial Services.' In 1947 the position remains as it was in 1939. 'The Union has had, since I925, an Ethnological section of the Native Affairs Department and its slender staff, headed by Dr. Van Warmelo, has done good work. The Native Affairs Department numbers among its officers many men who, as the writer of this Note can testify from recent personal experience, have wide and accurate knowledge of the peoples among whom they have laboured, some for thirty or forty years, and speak the languages fluently. A large proportion of them are sons of missionaries, born and bred among the Native people. But the most experienced of them are the first to lament that their knowledge is extremely limited, being confined to the tribes of which they have personal experience. They know little or nothing of the peoples outside the Union and of the great developments that are taking place in the British, French, and Belgian territories. One highly placed officer went on a tour of inspection to Nigeria; and some British officials have toured native areas of the Union. It would be to the mutual advantage of all the territories if interchange of this sort were greatly extended, for the Union has something to teach and something to learn. The Native Affairs Commission have proposed this. And it would be, in our opinion, highly profitable to the Union if the present hiatus between the Native Affairs Department and the University Schools of Bantu Studies were closed and if a training on the lines of that given to British, French, and Belgian officers were made available to, and required of, South Africans in their own institutions. At present there is no organized training in Bantu studies whether before or after appointment to responsible posts in the Native Affairs Department.

\section{Bursaries for African Medical Training in S. Rhodesia}

THE Government has announced that provisions have been made for a bursary to allow one African student a year to take his degree at a Union University. These bursaries are to carry a value of $f_{1} 100$ for the first year at Fort Hare and then $f_{250}$ per annum for the following five years at the University. It is the intention of Government, if suitable Africans are available, to allocate a bursary each year so that after six years there will be possibly six Africans receiving bursaries to assist medical training. The interest accruing from the Admiral Tait Memorial Fund is to be used to assist these students to buy books, \&c.

\section{Les Etudes Sociologiques en A.E.F.}

UN arrêté du Gouverneur Général crée à Brazzaville une 'Commission d'Études Sociologiques ' composée des chefs des services dont l'activité est plus particulièrement intéressée par les questions sociales. La commission est chargée de:

I. Coordiner l'organisation des enquêtes sociologiques sur le territoire de l'A.É.F.

2. Faire rassembler tous les renseignements d'ordre sociologique obtenus par les divers services du Gouvernement Général: 
3. Soumettre au Gouverneur Général les propositions de mesures sociales qu'elle jugerait utiles pour le progrès des populations de l'A.É.F.

Ainsi, c'est à Brazzaville qu'il appartenait d'avoir, la première dans l'Union Française, un organisme qui officiellement se penchât sur les importants problèmes que le plan d'enquête de l'Institut d'Études Centrafricaines se propose d'étudier. Ce plan, dont l'execution demandera plusieurs années, prévoit:

(a) L'étude de l'organisation sociale actuelle des populations de l'A.É.F.

(b) L'étude de l'organisation économique de la collectivité et de la famille.

(c) L'étude de la main-d'œuvre indigène.

(d) L'étude de l' ' urbanisation'.

(e) Des renseignements démographiques et sanitaires.

Les études sociologiques ainsi entreprises en A.É.F. viendront compléter et permettre des comparaisons utiles avec les études du même ordre prévues dans les autres territoires de l'Afrique Central; c'est-à-dire, le plan septennal de techerches établi par le RhodesLivingstone Institute, s'étendant sur la Rhodésie du Nord, la Rhodésie du Sud et le Nyasaland; au Congo Belge, les études du 'Centre d'Études de Politique Sociale Indigène', à Élisabethville, et celles du 'Centre d'Études Sociales Africaines' récemment créé à Léopoldville.

Ainsi, avec la Commission d'Études Sociologiques de Brazzaville et le plan de travail de l'Institut d'Études Centrafricaines, la France pourra apporter une contribution fructueuse à l'évolution des populations d'Afrique Centrale.

\section{Semaine de Missiologie de Lowain}

Pour la première fois depuis $\mathrm{x} 937$, la Semaine de Missiologie a eu lieu à Louvain au mois d'août, 1946. La session d'études a été consacrée au problème de La Famille Noire en Afrique. Le Rév. Père Decker et Dom Arnold Storms, O.S.B., ont parlé des conséquences de la puissance de la 'famille clanique '- des avantages économiques et sociales, ainsi que des inconvénients au point de vue personnel et strictement familiale. M. Antoine Sohier, Conseiller à la Cour de Cassation d'Élisabethville, a soulevé la question importante du mariage coutumier indigène; le Rév. Père Declercq, C.S.Sp., à donné une conférence sur la signification de la dot en droit coutumier congolais. M. Possoz a ajouté quelques précisions juridiques.

\section{Bulletin de Jurisprudence des Tribunaux Indigènes du Ruanda-Urundi}

Issued by l'Association des Anciens Élèves d'Astrida, this little publication, which is to appear twice a year, is concerned with the administration of law by the native tribunals of Ruanda-Urundi. The first number, issued in May I 946, contains an analysis, by G. Mineur, of the practice of native courts and its influence on customary law, an account of the law relating to guardianship by S. Gratien, and reports of a selection of court cases, with explanatory notes and comments on the judgement given in each case.

The bulletin is designed for 'tous les évolués qui ont à cœur de voir tégner la justice parmi les autochtones du pays ', and is prefaced by a foreword written by the vice-governor general of Ruanda-Urundi.

\section{The use of the ideophone by educated Africans}

We pass on to our readers a question raised by Mr. C. M. N. White, District Commissioner in Northern Rhodesia. 